\title{
How to Implement Product Requirements for Market Niches with Innovative Business Processes
}

\author{
Rosanna Fornasiero and Andrea Zangiacomi \\ Institute of Industrial Technologies and Automation \\ National Research Council, Via Bassini 15, \\ 20133 Milano, Italy \\ \{Rosanna.Fornasiero, Andrea.Zangiacomi\}@itia.cnr.it
}

\begin{abstract}
In order to stay competitive, European manufacturing companies need to enter new markets implementing innovative business processes based on networking economy. Through business processes and requirements analysis hold on some European SMEs, this work proposes a supply chain mapping of the most relevant processes, procedures and techniques comparing European fashion supply networks through multiple case studies. The innovative production model will be based on the integration of fashion companies towards both suppliers and customers to support sustainable production of small series addressed products for target groups like obese, disabled, elderly people.
\end{abstract}

Keywords: Fashion sector, supply collaborative networks, target groups, business and customer requirements.

\section{Introduction}

This work is part of a research framework held at European level aiming at implementing innovative tools and methods for supply chain management to support European Textile, Clothing and Footwear Industry (TCFI) to produce small series of functional and fashionable footwear and clothing of high quality, affordable price and eco-compatible. The model of networked small series production will be tested specifically for target groups like disable, diabetic, obese and elderly people.

As the manufacturing sector in general, the combined effects of labour intensity, low entry and exit barriers, and changes in international trade regulations have made TCFI a global industry, where competition is planetary and key players are both in Europe and North America as well as in emerging low labour cost countries [1]. Small firms have struggled to survive, often unsuccessfully, and have been progressively weeded out [2]. Moreover, the overall performance of TCFI is deeply affected by unpredictable and seasonal demand as well as emerging consumers' needs in terms of comfort, health and environmental attention [3].

This context forces European TCFI companies to rethink their market as well as their operations strategies. To stay competitive, EU manufacturing companies need to enter markets which are not reachable yet by competitors from low cost countries providing customers with innovative products where healthy and functional 
requirements related, for example, for what concerns shoes, to prevention of foot pain and injuries, should be complaint with fashion and aesthetic needs.

This work specifies in detail relevant as-is business processes and the to-be business requirements of each of the TCFI analysed company and of their networks to define a new collaborative supply chain reference model. Analysed companies represent both the perspective of traditional producers (from shoe and garment sectors) and of innovative players like online shirt sellers and shoe producers based on advanced technologies. Also technology providers like digital printing providers and service providers like foot monitoring devices producers are analyzed to understand how to implement the customer functional requirements with their support. This view on different type of TCFI networks will allow to have an holistic approach to the solutions to be proposed, which should fit with the need of producers, suppliers and customers.

\section{$2 \quad$ Literature Review}

Competition within TCFI is nowadays among global networks and key issues are how to develop and implement innovative managerial models and methods to support collaborative practices [4] [5]. The new paradigm of demand-driven supply networks [6], [7] emerges as a collaborative scheme to better respond to consumers' direct signals and needs. Moreover, as Adler [8] effectively discussed, the new enlarged/extended structures, characterized by high cognitive content exchanges, can no longer be coordinated by traditional hierarchy/market instruments as they require trust in order to share knowledge and leverage on external, updated and complementary competencies (i.e. Open Innovation model).

Along this vein Camarinha-Matos [9] investigate collaborative networks as new research field, analysing the different types, forms, characteristics and pre-conditions need for their development. Cooperative networks are formed to combine their core competences to be able to react to the requirements of their turbulent environments.

Companies need to improve their competences significantly through new business models, up-to-date strategies, technological capabilities and processes. Companies are increasingly restructuring their internal operations, information systems, production processes as well as collaboration strategies with other firms in complex value chains, business ecosystems, which extend globally [10]. These collaborative business networks are complex entities, where proper understanding for designing, implementing and managing is needed, for business success based on collaborative decision making [11]. Virtual Organization Breeding Environment (VBE) or Virtual Organization (VO), are models for long term and short term strategic alliances respectively [12, 13]. In particular in Romero and Molina [13] a complete framework of the business processes for VBE and VO is proposed and can be partially useful also for this work when specific business opportunities are encountered by a network of companies.

\section{The TCFI Context: Industries Facing New Market Needs}

The TCFI in Europe consists of more than 267.000 enterprises (about 90\% SMEs), approximately 3 million employees and a turnover of around €235 billion [14], [15] 
for a total impact on the European GDP for 4\% [16]. Total value added produced by the sector is around $€ 65$ billion. After China, the EU is the world's second largest exporter of textile products with 31\% including intra-EU trade. In 2010 the EU exported $€ 33.8$ billion worth of textiles and clothing products and continues to dominate global markets for up-market and high quality textiles and clothing. The EU is also a major producer and exporter of footwear, especially high quality, high value fashion shoes. In 2010 the EU was the second global exporter of footwear exporting $€ 4.9$ billion worth of shoes globally. However, contrary to the overall trend in the EU-27's manufacturing industry, in the past decade the sector's added value has fallen by over $40 \%$ (50\% in the case of clothing and even $60 \%$ in the case of footwear). Employment in the sector followed a similar downward trend [17].

Trade liberalisation does not seem to have had a decisive impact on this trend in the sector. It was indeed affected by other key factors including, in particular, changes in distribution and supply due to new environmental standards and health protection, rising energy and transport costs, which are making salaries less of a key factor in setting the end prices for goods, and changes in exchange rates [16].

Companies must turn these challenges into opportunities by improving their efficiency and by increasing innovation and excellence.

Small and medium-sized enterprises (SMEs) dominate the TCFI and each of them produces at one process stage. As for all TCFI companies, manufacturers are tightly integrated in European-wide networks covering the whole production chain starting from (chemical) fibre production up to the finished garments (representing roughly the $40 \%$ of the market for textiles) and technical textiles applications (60\%) in aerospace industry, construction, automotive, and - of course - also in footwear.

The TCFI networks do not only consist of companies along the production chain but also of suppliers (e.g. trimmings for garment or chemicals for treatment and components as soles, insoles and lasts for shoes) and service providers (from design centers, to development services, to production services for garment cut-make-trim, to quality checker, to maintenance service providers, to third party logistics providers, to distribution centers). The improvement of productivity, flexibility and quality of one company in the network will directly influence the competitiveness of the whole network.

At European level SMEs are most of the time grouped in regional clusters with an high level of industrial homogeneity. This structure can be considered as both a strength and a weakness, as SMEs are generally more flexible, and yet at the same time more likely to lack investment capability.

As above mentioned, today, the European TCFI is strongly pulled by a highly unstable and rapidly changing demand, due to fashion-related and seasonal fluctuations, as well as emerging consumers needs in terms of well being, health and sustainability. For this reason measures to diversify and to help and support SME to develop niche markets are key elements: the future of the TCF sector depends on the manufacturing of high-tech, innovative or fashionable products with high added value, which meet consumer needs. [16].

There is in fact a share of market willing to buy products not only for low price but also for their performance in terms of comfort, health care, and environmental attention [18]. The increasing demands for socially and environmentally accountable 
industrial production represent a challenge for European companies. The need for environmental protection could in fact provide the sector with new opportunities, in terms of both the adoption of new production processes and the development of new products and materials [16].

More and more, firms need to pursue innovation strategies based on creativity, quality and differentiation to realize more complex products focused on different kind of customers and their specific needs. Small and specialized companies can face this challenge only working in demand-driven and customer oriented networks. Small series and specialized high value added products are a key opportunity for knowledge base European SMEs in the consumers goods sector [16][18]. In particular here the specific consumer target group addressed are elderly, obese, diabetics, and disables.

\subsection{New Market Niches}

The target groups addressed represent a large share of European citizens, according to present figures hereafter described. As underlined in the last resolution of the European Parliament the diabetes epidemic is a pressing issue. There are now more than 32 million EU citizens living with diabetes, which amounts to $8.1 \%$ of the adult population. This figure is set to rise to 50 million - $10 \%$ of the EU population - by 2025. Besides, Europe has the highest numbers of children with Type 1 diabetes. Each year, diabetes and related complications claim the lives of 325,000 EU citizens [19]. For what concerns elder people, in 2010 the population aged 65 years or over accounted for $17.4 \%$. By 2050, the number of people in the EU aged 65 and above is expected to grow by $70 \%$ and the number of people aged over 80 by $170 \%$ [20]. Obesity is one the major health challenges worldwide and has become an epidemic over the last decades. Europe has the highest number of overweight and obese people in the world. The number of obese people has in fact tripled over the last 20 years in the Europe, according to the WHO [21]. Today, over 130 million people are obese in Europe and 400 million people are overweight. Moreover there are 80 million Europeans with disabilities. This is over $15 \%$ of the whole population. One in four Europeans has a family member with a disability [22]. In conclusion, it has also to be underlined that the four target groups are not completely separated both in terms of physical diseases and functional needs. As underlined by the EU commission, these data raises important challenges for the 21st century: meet the higher demand for healthcare and also for specific requirements.

The above mentioned categories in fact need products to fulfil their requirements in terms of improved comfort and functionalities of wearables, which is to protect the body from regular environmental impact (e.g. heat, cold, water, humidity) in a high comfort and high quality. High comfort means perfect fit, easy to dress/undress or low effort for washing and ironing. High quality means long-lasting appearance in terms of colour and shape, perfect assembly (durable seams) and high quality of material. Particularly, comfort in shoes is very important for elderly, obese, diabetics and disabled people due to changes in the foot morphological shape and bone disease which may cause problems during walking and standing. The business opportunity here described is to provide mainly products for preventive reasons and first level of disease. The focus is set on fashion companies willing to enlarge their business, 
covering a market niche that otherwise is not considered since the only specific products offered to these consumers are orthopaedic ones and generally products with medical prescription. Anyway it is important for companies to be supported by experts in the field to design and produce these kind of new added value products.

\section{Customer and Business Requirements}

\subsection{Product Requirements from Target Groups}

Main requirements from the TGs collected for the scope of the work are based both on interviews with people belonging to the categories and to experts like doctors and companies already producing for the TGs. Approximately $10-25 \%$ of all diabetics develop some foot problems during the course of their illness from simple calluses to major abscesses and osteomyelitis. Moreover nerve damage from diabetes can cause lose feeling in feet which makes difficult to be aware of pain and injuries caused by incorrect shoes or walking behaviours [23]. Foot injuries in diabetics can cause ulcers and infections and for this reason it is important to wear correct shoes and monitor the status of foot pressure on the insole using special customized shoes, with sensors [24]. In case of fashion companies willing to produce goods for preventive reasons the focus should be limited to diabetic people of category 0 (high foot risk and no ulceration) and I (superficial ulcer), according to the Wagner's classification of the diabetic foot [25]. This represent an important preventive approach aiming to provide diabetic people, which have not already incurred in heavy consequences of their condition, with not specifically medical products able to support them in avoiding possible foot problems. The impact in terms of future benefits is relevant if we consider not simply the percentage of diabetics covered but the fact that this approach is addressed to all diabetics at the beginning of their illness and will help them in maintaining the initial health condition of their feet, improving their future quality of life. Moreover it is an approach allowing also fashion companies to approach a new market without the need to enter into the system of the National service support for medical products.

Table 1. Target groups requirements

\begin{tabular}{|c|c|c|}
\hline & REQUIREMENT & CATEGORY \\
\hline \multicolumn{3}{|c|}{ Product structure, components and materials } \\
\hline Specific features required for product components & $\begin{array}{l}\text { Control the shape of the components, rigidity, } \\
\text { dimensions. }\end{array}$ & $\begin{array}{l}\text { Diabetics, Elderly, } \\
\text { Obese }\end{array}$ \\
\hline Specific properties required for materials & $\begin{array}{l}\text { Possibility to choose materials according to } \\
\text { functional specifications like transpirancy, anti- } \\
\text { sweating, anti-allergic, softness. }\end{array}$ & $\begin{array}{l}\text { Diabetics, Elderly, } \\
\text { Obese, Disable }\end{array}$ \\
\hline Specific properties required for the whole & $\begin{array}{l}\text { Control stability, shock absorbtion, skin/bone } \\
\text { protection, easy to dress }\end{array}$ & $\begin{array}{l}\text { Diabetics, Elderly, } \\
\text { Obese, Disable }\end{array}$ \\
\hline \multicolumn{3}{|l|}{ Size \& fit } \\
\hline Need to redistribute feet pressure and pressure points & $\begin{array}{l}\text { Insole realized according to measured } \\
\text { walking pressure }\end{array}$ & $\begin{array}{l}\text { Diabetics, Obese, } \\
\text { Elderly }\end{array}$ \\
\hline Need to adapt product design to body shape & Morphotype & Obese \\
\hline Need to adapt product design to foot shape & Last realized according to feet geometry & $\begin{array}{l}\text { Diabetics, Elderly, } \\
\text { Disable }\end{array}$ \\
\hline
\end{tabular}


Obesity is a medical condition in which excess body fat has accumulated to the extent that it may have an adverse effect on health. It is defined by Body Mass Index (BMI) and further evaluated in terms of fat distribution via the waist-hip ratio and total cardiovascular risk factors. In this category focus is on people from obesity class I, which includes, referring to obesity classification established by the World Health Organization (WHO) in 1997 and published in 2000 according to BMI, values in the range 30-35. Associated needs are for special reinforced shoes and oversize shirts and garments. All products should also be realized with materials able to guarantee the best comfort and to respond to specific requirements of the group as, for example, anti-sweating features. Regarding dimensions, these products don't have the same proportions as the normal size products and so it is not only a matter of expanding the number of sizes in catalogue but specific rules have to be used during the design phase. Each person needs personalized shoes and garment according to a series of parameters which have to be defined and measured by companies.

In case of disability it is more difficult to categorize and define features and specifications which are valid for the category, In fact it is a very heterogeneous field and include many different kinds of pathologies. For this work the focus is on people with mobility limitation, in particular those using wheelchairs, and people with difficulties in dressing up and undressing. People with mobility limitation need to use customized shoes and garments very easy to dress up like for example with Velcro opening and elastic bands, to avoid tiny buttons and laces. Moreover measurements and size can be different from normal size due to permanent sitting position.

Elderly is a wide category and for the purpose of this work have been considered in particular elderly with mobility problems due to deformity of feet. Elders feet have often decreased plantar sensory, fragile skin and reduced healing abilities and need to be protected from possible hazard in environment. For these reason elderly people need special customized comfort shoes [26]. Moreover falls, particularly injurious ones, are a significant problem for the elderly. Although falls have multifactorial causes, foot problems and inappropriate footwear have been established as major falls risk factors for this population [27]. For very old people with mobility problems requests are similar to the ones of disabled.

In table 1 requirements for all the different categories are summarized according to different aspects in order to underline how the needs of the four target groups are often common and overlaps.

\subsection{New Business Processes from TCFI Companies}

As previously underlined TCFI Supply chain is characterized by many small companies collaborating each other along the value chain. Beside big brands like Zara, H\&M, Benetton there are many own brand producers which cover a reasonable market share producing mainly high quality products sold all over the world. While most business networks have been formed along the value chain and were formed for long-time purpose, the current market asks for more flexible organizational structures which can quickly adapt to new customer needs and challenges. Therefore these networks have much shorter life-time and capitalize a lot on the concept of virtualization. Distributed information and knowledge are seen as main assets within such networks. Fashion is one of the industries more exposed to direct market 
evaluation, and focal companies are responsible for their products both in terms of economic performance and environmental and social problems caused not only by themselves directly, but also by their suppliers.

An innovative group of companies from TCFI have been chosen and includes SMEs aiming to radically change their business model and supply chain structure, leveraging on environmental sustainability to compete in new market niches like disable, diabetic and obese people to provide healthy and fashionable products.

Research methodology has been based on business case analysis, interviews with managers, brainstorming with operations managers. BPMN formalization has clearly revealed which are the processes where fashion companies should implement changes to address the needs of the target groups and improve their supply network operations and identifying the potential benefits of methods and supporting tools. The summary of the requirements collected for process improvement for a new supply chain approach have been summarized in table 2. Here the main actors of the different process are highlighted. It has to be underlined that customers for small series can be both retailers interested in the realization of a small collection for a target group or end customers belonging to one (or more) target group that want to purchase a product according to their specific needs. Also for what concerns experts, different typology are considered. In CD1, where needs of TGs and functionalities for new product have to be defined, actors include medical experts whereas in CD2 it is foreseen the support of technical experts in the implementation of the selected functionalities like insole medical suppliers in the case of footwear.

Table 2. New business Processes and related Requirements

\begin{tabular}{|c|l|l|l|}
\hline Id & \multicolumn{1}{|c|}{ Process Requirement description } & Main Actors & Process \\
\hline IM1 & $\begin{array}{l}\text { Traditional shopping support for specific } \\
\text { customer groups: Direct customer acquisition of } \\
\text { footwear, textiles or clothing products should be } \\
\text { supported by the possibility to manage special } \\
\text { features for the consumer target groups (elderly, } \\
\text { obese, diabetics and disabled people) with the } \\
\text { possibility of product configuration both } \\
\text { aesthetically and functionally. Full visualization of } \\
\text { products characteristics with advanced rendering } \\
\text { systems. }\end{array}$ & $\begin{array}{l}\text { End-Customer, } \\
\text { phop assistant, }\end{array}$ & $\begin{array}{l}\text { Sales, product } \\
\text { configuration }\end{array}$ \\
\hline IM2 & $\begin{array}{l}\text { Online visualization, configuration and acquisition } \\
\text { of garment/leather/footwear product: customer } \\
\text { acquisition of product special features, configuration } \\
\text { and full visualization of products characteristics } \\
\text { through online systems for collaboration during sales } \\
\text { process }\end{array}$ & $\begin{array}{l}\text { End-Customer, } \\
\text { retailer, producer }\end{array}$ & $\begin{array}{l}\text { Sales, product } \\
\text { configuration }\end{array}$ \\
\hline
\end{tabular}


Table 2. (Continued)

\begin{tabular}{|c|c|c|c|}
\hline CD1 & $\begin{array}{l}\text { Co-design with support of Knowledge } \\
\text { Management Tools: Through data mining } \\
\text { approaches, consumer-oriented market analysis } \\
\text { should be useful to define needs of customer } \\
\text { segments. Subsequent knowledge management } \\
\text { tools can support designers in the identification of } \\
\text { market needs and consumer preferences for new } \\
\text { products and functionalities in the footwear and } \\
\text { accessories, textile and garments sectors. }\end{array}$ & $\begin{array}{l}\text { Marketing } \\
\text { managers, } \\
\text { Trendsetter, } \\
\text { Medical experts }\end{array}$ & Market analysis \\
\hline CD2 & $\begin{array}{l}\text { Definition of Collection for specific target } \\
\text { groups: this implies to have a collaborative } \\
\text { environment where different type of users (internal } \\
\text { and external to the company) with different roles } \\
\text { (and IT skills) can contribute to define a collection } \\
\text { of suitable products for the target consumers. }\end{array}$ & $\begin{array}{l}\text { Managers, } \\
\text { Stylists, main } \\
\text { suppliers, } \\
\text { Designers, } \\
\text { Technical experts }\end{array}$ & Design phase \\
\hline CD3 & $\begin{array}{l}\text { Product Design with CAD modelling support: } \\
\text { This activity is carried out by the (internal and } \\
\text { external) designers and produces the CAD technical } \\
\text { models of the product. Also includes selection of } \\
\text { materials for both clothing and footwear. }\end{array}$ & $\begin{array}{l}\text { Customers } \\
\text { (retailers), } \\
\text { Designers, } \\
\text { modelists }\end{array}$ & Design phase \\
\hline CD4 & $\begin{array}{l}\text { Process planning support: Process planning is } \\
\text { related to product engineering and has the aim to } \\
\text { decide how to manufacture the product and to } \\
\text { produce all related information. In this phase } \\
\text { suppliers and outsourcers are identified and defined } \\
\text { and the costs for the different manufacturing phases } \\
\text { are fixed. Also the BOM, the working cycles and } \\
\text { the production times of the new product model are } \\
\text { also defined. }\end{array}$ & $\begin{array}{l}\text { Producers, } \\
\text { Suppliers, } \\
\text { outsourcers }\end{array}$ & Process planning \\
\hline CM1 & $\begin{array}{l}\text { Partner Search support: partner search is a } \\
\text { process embedded in other processes like Process } \\
\text { planning in CD4 and CP2 as well as CP3. } \\
\text { Companies need support for the identification of the } \\
\text { correct performance indicators to be used for the } \\
\text { search and selection. Suppliers and outsourcers can } \\
\text { be involved in the collaborative definition of the } \\
\text { indicators and in the monitoring activities. }\end{array}$ & $\begin{array}{l}\text { Production } \\
\text { managers, } \\
\text { designers, } \\
\text { suppliers, } \\
\text { outsourcers }\end{array}$ & $\begin{array}{l}\text { Design phase, } \\
\text { process } \\
\text { planning, } \\
\text { production } \\
\text { planning }\end{array}$ \\
\hline $\mathrm{CP} 1$ & $\begin{array}{l}\text { Customer order processing support: Automatic } \\
\text { pre-processing of customer orders for } \\
\text { administrative and pre-production checks and } \\
\text { issues. The final output is the list of customer } \\
\text { orders ready to be processed for production. }\end{array}$ & $\begin{array}{l}\text { Production } \\
\text { manager }\end{array}$ & $\begin{array}{l}\text { Order } \\
\text { management }\end{array}$ \\
\hline
\end{tabular}


Table 2. (Continued)

\begin{tabular}{|c|c|c|c|}
\hline $\mathrm{CP} 2$ & $\begin{array}{l}\text { Support for collaborative process planning: after } \\
\text { order collection process planning done in CD } 4 \\
\text { needs to be specified for creation of set of } \\
\text { Production Orders; external activities (to be } \\
\text { outsourced) require the identification of potential } \\
\text { partners to be assigned. The output is the set of } \\
\text { production orders ready to be scheduled. }\end{array}$ & $\begin{array}{l}\text { Production } \\
\text { manager, } \\
\text { Supplier, } \\
\text { Outsourcer }\end{array}$ & Process planning \\
\hline $\mathrm{CP} 3$ & $\begin{array}{l}\text { Collaborative production planning and control: } \\
\text { Production Orders related to the same customer's } \\
\text { orders can be scheduled using a collaborative tool } \\
\text { where Manufacturer and Partners can share a view of } \\
\text { the production order schedules and close a } \\
\text { "negotiation" for the definitive launch of } \\
\text { manufacturing activities. The result is a set of } \\
\text { production orders scheduled and ready to be } \\
\text { launched. }\end{array}$ & Manufacturer & $\begin{array}{l}\text { Production } \\
\text { planning and } \\
\text { control }\end{array}$ \\
\hline $\mathrm{CP} 4$ & $\begin{array}{l}\text { Partner monitoring and trace support: } \\
\text { Production Orders launched can be monitored and } \\
\text { KPI related to Quality and Sustainability can be } \\
\text { evaluated for that specific set of production orders. } \\
\text { The outcome includes overall status, } \\
\text { alerts/warnings and KPIs. }\end{array}$ & $\begin{array}{l}\text { Manufacturer, } \\
\text { Supplier, } \\
\text { Outsourcer }\end{array}$ & $\begin{array}{l}\text { Production } \\
\text { planning and } \\
\text { control }\end{array}$ \\
\hline TP1 & $\begin{array}{l}\text { Technologies to support aesthetical } \\
\text { personalization: This process includes sustainable } \\
\text { and flexible Digital (Textile) Printing using } \\
\text { textured markers and the application of a decoration } \\
\text { design (as included in the CAD design) through a } \\
\text { laser engraving machine, on leather components of } \\
\text { a possibly customized product in leather, like shoes } \\
\text { or leather clothes. }\end{array}$ & $\begin{array}{l}\text { Manufacturer, } \\
\text { Outsourcer }\end{array}$ & Production \\
\hline TP2 & $\begin{array}{l}\text { Technologies to support functional } \\
\text { characterization: (insole and last - make to } \\
\text { measure) this process is referred to footwear } \\
\text { scenario and includes the outsourced realization of } \\
\text { a customized insole according to results from foot } \\
\text { pressure measurements by sensors and of a } \\
\text { customized last in case of made to measure shoes. }\end{array}$ & $\begin{array}{l}\text { Manufacturer, } \\
\text { Supplier, } \\
\text { Outsourcer }\end{array}$ & Production \\
\hline
\end{tabular}

In table 3 are indicated important relationships between the functional requirements and analyzed companies and it shows how, according to the type of company, different process improvement are necessary.

The process change requirements cover the major coordinated intra- and intersector networking of producers/service providers using innovative production technologies as well as innovative organizational models based on cross-supply network integration and collaboration. New actors and new interaction mechanisms are part of the networks and new level of information should be exchanged both in terms of product and process improvement. 
Table 3. Process Requirements-Company matrix

\begin{tabular}{|c|c|c|c|c|c|c|c|c|c|c|c|c|c|}
\hline $\begin{array}{c}\text { Requirements } \\
\text { Vs } \\
\text { Companies }\end{array}$ & Sector & IM1 & IM2 & CD1 & CD2 & CD3 & CD4 & CP1 & CP2 & CP3 & CP4 & TP1 & TP2 \\
\hline $\begin{array}{c}\text { Make-to } \\
\text { measure } \\
\text { producer }\end{array}$ & Clothing & & $\checkmark$ & $\checkmark$ & & $\checkmark$ & $\checkmark$ & $\checkmark$ & $\checkmark$ & $\checkmark$ & $\checkmark$ & $\checkmark$ & \\
\hline $\begin{array}{c}\text { Technology } \\
\text { provider }\end{array}$ & Clothing & & & & & & $\checkmark$ & $\checkmark$ & & & & $\checkmark$ & \\
\hline $\begin{array}{c}\text { Traditional } \\
\text { producer }\end{array}$ & Footwear & $\checkmark$ & $\checkmark$ & $\checkmark$ & $\checkmark$ & $\checkmark$ & $\checkmark$ & $\checkmark$ & $\checkmark$ & $\checkmark$ & $\checkmark$ & $\checkmark$ & \\
\hline $\begin{array}{c}\text { Mass } \\
\text { customization } \\
\text { producer }\end{array}$ & Footwear & & $\checkmark$ & $\checkmark$ & & $\checkmark$ & $\checkmark$ & $\checkmark$ & $\checkmark$ & $\checkmark$ & $\checkmark$ & $\checkmark$ & $\checkmark$ \\
\hline $\begin{array}{c}\text { Traditional } \\
\text { producer }\end{array}$ & Clothing & $\checkmark$ & $\checkmark$ & $\checkmark$ & $\checkmark$ & & $\checkmark$ & $\checkmark$ & $\checkmark$ & $\checkmark$ & $\checkmark$ & & \\
\hline $\begin{array}{c}\text { Service } \\
\text { provider }\end{array}$ & Footwear & & $\checkmark$ & & & $\checkmark$ & & $\checkmark$ & & & & & $\checkmark$ \\
\hline
\end{tabular}

\section{$5 \quad$ Conclusions and Ongoing Developements}

The approach proposed in this paper allows to cover many different issues along the supply network. From the customer interaction point of view, what emerges is that companies need to change the way customers are involved in the design and production process to be able to interact with them. This happens to collect first information on market trends for understanding new target groups, and second information about product functional characteristics via web-based configurators. This means to support fashion companies to reach customer satisfaction not only through aesthetic details but also and mainly with application of new materials (e.g. transpirant, waterproof, flexible materials..), customized production processes (e.g. no internal stitching for diabetics..) or new components (e.g. personalized insole..) to make shoes and garment more comfortable to prevent injuries and pain.

Consumer requirements emphasize the need to apply different level of customization and product personalization and this can be taken into consideration according to the type of company willing to implement this production model: while traditional companies are interested to small series production, innovative companies are more oriented to a make-to-measure approach or to a configure-to-order approach.

From the supply chain management point of view, to increase capabilities of companies to produce small series means to formalize partner search and selection to ease the quick reconfiguration of networks. In fact in the fashion sector there is the need to define framework agreements at the beginning of the season so that suppliers and outsourcers allocate capability to a certain production and during the season they are ready to answer to production needs according to specific requests.

Comparing some European fashion supply networks through multiple case studies, this work proposes innovative business processes that support the implementation of fashion products based on functional requirements of niche markets represented by elderly, diabetic, obese and disabled people. 


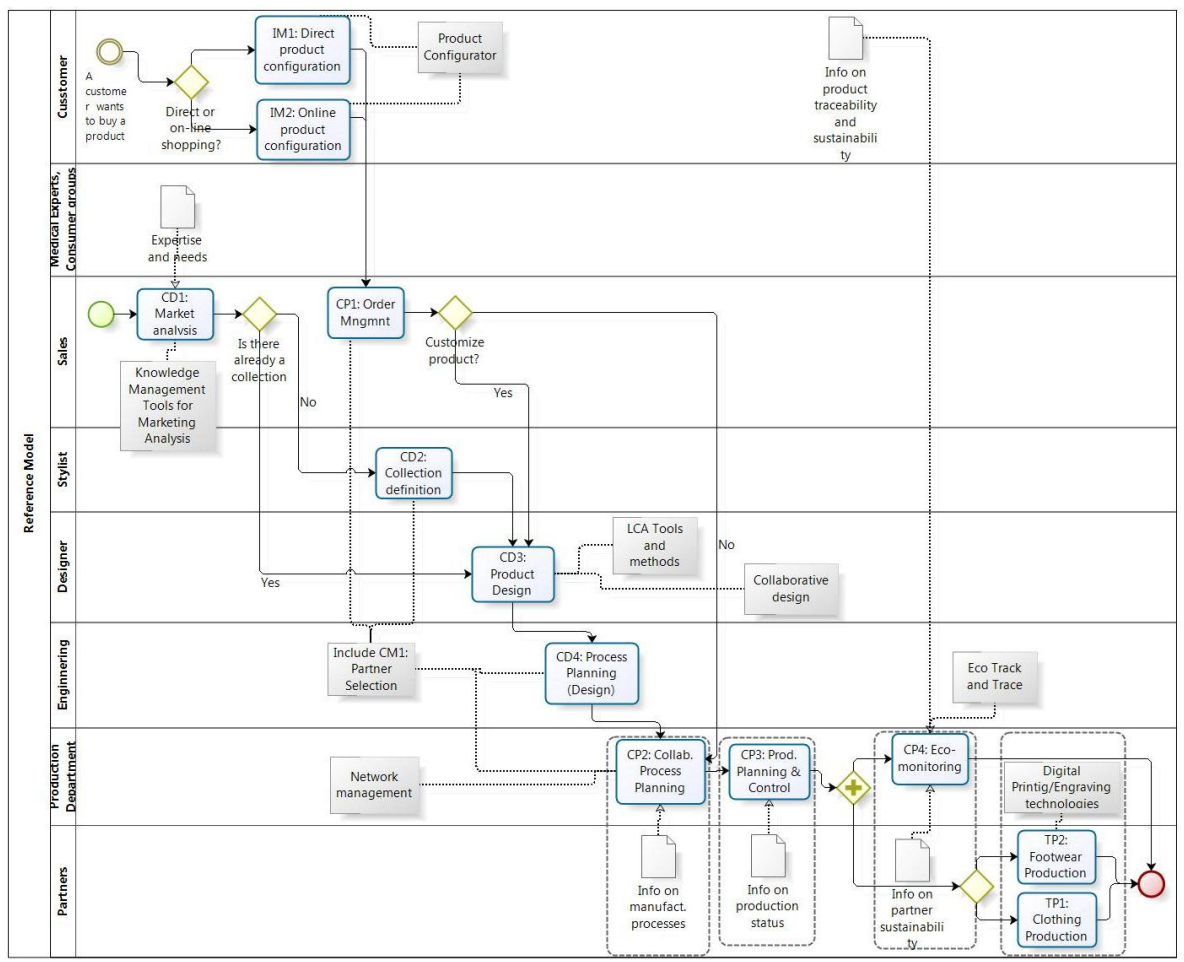

bizagil

Fig. 1. The high level of the Reference Model

The functional requirements analysed and previously presented call for new approaches to TCFI business process management and have been then also used to develop a specific reference model based on the definition of three important dimensions in the networked companies (as from the model proposed in [29]): ICT, knowledge and organization. For each of the process the three dimensions have been developed both in terms of innovative practices and of related tools. The high-level of the reference model is shown in figure 1 and represents an outlook on the business processes summarizing the whole flow which is then developed in details at tactical level. This detailed level of the Reference Model is undergoing a further refinement based on best practices collected from literature and case analysis.

Acknowledgments. This work has been partly funded by the European Commission through the FP7-2010-NMP-ICT-FoF Project CoReNet: 'Customer-Oriented and EcoFriendly Networks for Healthy Fashionable Goods' (Grant Agreement 260169). The authors wish to acknowledge the Commission for their support. We also wish to acknowledge our gratitude and appreciation to all the CoReNet project partners for their contribution during the development of ideas and concepts presented in this paper. 


\section{References}

1. Gereffi, G., Humphrey, J., Sturgeon, T.: The governance of global value chains. Review of International Political Economy 12(1), 78-104 (2005)

2. Leonidou, L.C.: An analysis of the barriers hindering small business export development. Journal of Small Business Management 42(3), 279-302 (2004)

3. TCFI ETPs: European Technology Platform for the Future of Textiles and Clothing (ETP FTC), http: / / www. textile-platform. eu

4. Dyer, J.H., Singh, H.: The Relational View: Cooperative Strategy and Source of Interorganizational Competitive Advantage. Academy of Management Review 23(4), 660679 (1998)

5. Camarinha-Matos, L.M., et al.: Towards a framework for Creation of dynamic virtual Organizations. IFIP International Federation for Information Processing, vol. 186, pp. 6980 (2005)

6. Childerhouse, P., Aitken, J., Towill, D.R.: Analysis and design of focused demand chains. Journal of Operations Management 20(6), 675-689 (2002)

7. De Treville, S., Shapiro, R.D., Hameri, A.: From supply chain to demand chain: the role of lead time reduction in improving demand chain performance. Journal of Operations Management 21(6), 613-627 (2004)

8. Adler, P.S.: Market, Hierarchy and Trust: the Knowledge Economy and the Future of Capitalism. Organization Science 12(2), 215-234 (2001)

9. Camarinha-Matos, L.M., Boucher, X., Afsarmanesh, H. (eds.): PRO-VE 2010. IFIP AICT, vol. 336. Springer, Heidelberg (2010)

10. Myers, J.: Future Value Systems: Next Generation Economic Growth Engines \& Manufacturing. In: Proceedings of the IMS Vision Forum 2006, Seoul, Korea, pp. 30-47 (2006)

11. Camarinha-Matos, L.M., Afsarmanesh, H.: A Comprehensive Modeling Framework for Collaborative Networked Organizations. J. Intell. Manuf. 18, 529-542 (2007)

12. Romeo, D., Galeano, N., Molina, A.: Virtual Organization Breeding Environments Value System and Its Elements. J. Intell. Manuf. 21, 267-286 (2010)

13. Romeo, D., Molina, A.: VO Breeding Environments \& Virtual Organizations Integral Business Process Management Framework. Information System Frontiers (ISF) 11, 569597 (2009)

14. (2007), http://ec.europa.eu/enterprise/textile/statistics.htm

15. (2008), http://ec.europa.eu/enterprise/sectors/footwear/ statistics/index_en.htm

16. The future of the textile,clothing and footwear sectors in Europe, EU Commission (2008)

17. (2010), http://ec.europa.eu/trade/creating-opportunities/ economic-sectors/industrial-goods/textiles-and-footwear.htm

18. Fornasiero, R., Chiodi, A., Carpanzano, E., Carneiro, L.: Research Issues on CustomerOriented and Eco-friendly Networks for Healthy Fashionable Goods. In: Ortiz, Á., Franco, R.D., Gasquet, P.G. (eds.) BASYS 2010. IFIP AICT, vol. 322, pp. 36-44. Springer, Heidelberg (2010)

19. http://www.idf.org/epresolution.htm

20. http://ec.europa.eu/health-eu/my_health/elderly/index_en.htm

21. http://www. who.int

22. http://www.edf-feph.org/ 
23. Frykberg, R.G., Lavery, L.A., Pham, H., Harvey, C., Harkless, L., Veves, A.: Role of neuropathy and high foot pressures in diabetic foot ulceration. Diabetes Care 21, 17141719 (1998)

24. Cavanagh, P.R.: Therapeutic footwear for people with diabetes. Diabetes Metab. Res. Rev. 20, 51-55 (2004)

25. Wagner Jr., F.W.: The diabetic foot. Orthopedics 10(1), 163-172 (1987)

26. Mickle, K.M., Munro, B.J., Lord, S.R., Menz, H.B., Steele, J.R.: Foot shape of older people: Implications for shoe design. Footwear Science 2(3), 131-139 (2010)

27. Mickle, K.M., Munro, B.J., Lord, S.R., Menz, H.B., Steele, J.R.: Foot pain, plantar pressures and falls in older people: A prospective study. Journal of the American Geriatrics Society 58, 1936-1940 (2010)

28. Fornasiero, R., Zangiacomi, A., Stellmach, D.: A Reference Model for Customer-Oriented and Eco-Friendly Networks for Healthy Fashionable Goods. In: Frick, J. (ed.) Proceedings of the APMS 2011 Conference - Advances in Production Management Systems, September 26-28, Published at the University of Stavanger, Norway (2011)

29. Filos, E., Banahan, E.: Towards the smart organization: An emerging organizational paradigm and the contribution of the European RTD programs. Journal of Intelligent Manufacturing 12(2), S.101-S.111 (2001) 